\title{
Response of Moderate Pest Resistant and Susceptible Cultivar of Sugarcane to Silicon Application
}

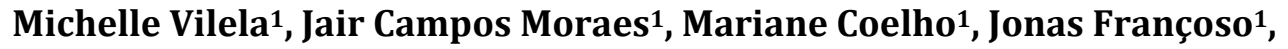 \\ Terezinha Monteiro dos Santos-Cividanes ${ }^{2}$, Roney Sakomura ${ }^{1}$ \\ ${ }^{1}$ Departamento de Entomologia (DEN), Universidade Federal de Lavras (UFLA), Lavras, Brasil \\ ${ }^{2}$ Agência Paulista de Tecnologia dos Agronegócios-APTA, Polo Regional Centro Leste, Ribeirão Preto, Brasil \\ Email: michellevilela@den.ufla.br, jcmoraes@den.ufla.br, c.mahh@yahoo.com.br, \\ jonasfrancoso@hotmail.com, terezinha@apta.sp.gov.br, roneysakomura@hotmail.com
}

Received 25 October 2014; revised 24 November 2014; accepted 4 December 2014

Copyright ( 2014 by authors and Scientific Research Publishing Inc.

This work is licensed under the Creative Commons Attribution International License (CC BY).

http://creativecommons.org/licenses/by/4.0/

(c) † Open Access

\begin{abstract}
In this study, the effects of a silicon (Si) application on the biomass, chlorophyll level and silicon level of sugarcane moderate pest resistance (RB72454) and susceptible (SP801842) cultivars were tested. Investigations were also carried out to assess the effect of silicon on Diatraea saccharalis infestation. The experiments were conducted in a greenhouse using the treatments consisting moderate pest resistant and susceptible culivar, with or without silicon application. The silicon was applied to the soil around the plants. The experiment was laid in complete randomized design with 4 treatments and 10 replicates. The data were subjected to an analysis of variance, and the averages were compared using the Tukey test $(p \leq 0.05)$. Significant changes were observed in the fresh and dry masses of the aerial portions and the root system, as well as in the plant chlorophyll and silicon levels. The silicon content increased in the susceptible variety which was significantly equal for moderate resistance variety. Chlorophyll content increased in silicon treated cultivars. Sixty days after the last application, 10 adult $D$. saccharalis moths were released onto each pot. However, due to the low infestation, the effects of silicon on the insect incidence could not be determined. One can conclude that silicon is beneficial for the growth of the aerial portions of sugarcane and causes a significant increase in chlorophyll levels.
\end{abstract}

\section{Keywords}

Insect, Diatraea saccharalis, Induced Resistance, IPM

How to cite this paper: Vilela, M., Moraes, J.C., Coelho, M., Françoso, J., dos Santos-Cividanes, T.M. and Sakomura, R. (2014) Response of Moderate Pest Resistant and Susceptible Cultivar of Sugarcane to Silicon Application. American Journal of Plant Sciences, 5, 3823-3828. http://dx.doi.org/10.4236/ajps.2014.526400 


\section{Introduction}

Brazil is currently the world's largest sugarcane producer, followed by India. More than 9 million hectares, yielding more than 700 million tons of sugarcane, are planted in Brazil each year. Within Brazil, São Paulo, Minas Gerais, Goiás and Paraná are the largest sugarcane-producing states [1].

Because of improvements in sugarcane production as well as the construction of sugar/alcohol facilities, several Brazilian states have begun planting more sugarcane. The sugarcane acreage in Brazil has increased by 171.7 thousand hectares (2.1\%), compared to the last harvest (2010/2011). The Southeast region showed the largest percentage growth (96.6\%) of sugarcane planting areas. Significant growth was also seen in the Midwest region. However, due to low soil moisture and the need to irrigate at planting, the costs of farming sugarcane were higher in many states [2].

This crop is severely damaged by $D$. saccharalis (Fabricius, 1794) (Lepidoptera: Crambidae) caterpillars, which feed by creating holes in the plant stalks. This insect is the most important pest for the sugarcane industry across all of the Americas [3] because it is difficult to control; the caterpillars, for the majority of the time are a threat, reside inside the stalks.

Sugarcane responds very well to silicon fertilization because it is a silicon-accumulating crop. The largest productivity responses in sugarcane are obtained in the first year after slag from steel mills and other sources is used as a fertilizer; the calcium silicates contained in the slag increase the plant's silicon absorption [4] [5]. In addition, technology based on silicon is clean and sustainable, leading increased productive and vigorness with less number of diseases or pests incidence [6].

This study was conducted to analyze the effects of silicon (Si) application on the vegetative growth of sugarcane cultivars RB72454 (with moderate pest resistance) and SP801842 (susceptible), as well as on their D. saccharalis infestations.

\section{Material and Methods}

The experiments were conducted from March to November of 2011 in a biochemical oxygen demand (BOD) climate-controlled chamber at the Plant Resistance to Insects Laboratory, as well as in a greenhouse at the Entomology Department of the Federal University of Lavras (Universidade Federal de Lavras-UFLA).

D. saccharalis specimens were raised from eggs provided by the Santa Adélia Sugar Mill (Jaboticabal, SP, Brazil). After hatching, the larvae remained in a BOD incubator at a temperature of $25^{\circ} \mathrm{C} \pm 2{ }^{\circ} \mathrm{C}$ with a relative humidity of $70 \% \pm 10 \%$ and a 12-hour light cycle. The larvae were fed a diet consisting primarily of soy meal, sugarcane yeast and sugar [7].

The billets used for planting contained one node (bud) plus half of the inferior and half of the superior internode. They were obtained from the middle third of the adult stalks of cultivars RB72454 (moderate resistance) and SP801842 (susceptible) provided by Itaiquara Sugar Mill (Passos, MG, Brazil) and the João Mendes Distillery (Perdões, MG, Brazil), respectively.

Polyethylene pots capable of holding $5 \mathrm{~kg}$ of soil were filled with earth (specifically latosol, which is dark red in color) and fertilized with $3.83 \mathrm{~g}$ of 4-14-8 fertilizer. Twenty pots of each sugarcane cultivar were planted and then layered over with $5 \mathrm{~cm}$ of soil. The plants were thinned 20 days after their emergence until two plants remained per pot. The pots were placed on benches in a greenhouse at the UFLA Entomology Department and watered to meet their hydration needs.

Two applications (500 mL each) of $1 \%$ silicic acid $\left(\mathrm{SiO}_{2} \cdot \mathrm{XH}_{2} \mathrm{O}\right)$ (Vetec Química Fina, Duque de Caxias, RJ, Brazil) were used per $5 \mathrm{~kg}$ pot which was equivalent to $4 \mathrm{t}$ of $\mathrm{SiO}_{2} /$ ha. The solution was applied to the soil surrounding the plants at 120 and 125 days after emergence. The control pots received $500 \mathrm{~mL}$ of water in each application.

Sixty days after the second silicon application (185 days after seedling emergence), 20 adult $D$. saccharalis moths were released onto each pot and covered with cage. The moths were no older than 24 hours and were raised from maintenance breeding. The cages were covered with cheesecloth that was $40 \mathrm{~cm}$ in diameter and $100 \mathrm{~cm}$ tall. The covering was place on the pot and supported by three quarter-inch iron bars fixed in the soil, and the bottom of the covering was held against the bottom of the pot by an elastic band.

Sixty days after release of caterpillars in the pot, chlorophyll levels in the sugarcane leaves were measured. The third completely formed leaf on each plant was collected between 8 and 10 o'clock in the morning and chlorophyll level measured using a SPAD-502 portable chlorophyll meter (Minolta Camera Co. Ltd., Osaka, 
Japan).

After chlorophyll levels measurement, the plants were cut at the soil level to separate the aerial portions from the roots, and both halves were washed.

The aerial portions of the plants were dissected, and a visual examination was made for the presence of "dead heart", caterpillars and their pupae.

For dry mass estimation, the separated plant materials were placed in a paper bag and kept in an incubator at $60^{\circ} \mathrm{C}$ until it reached a constant weight. After drying, the material was weighed to determine the average dry mass of aerial portions and roots.

To determine the silicon levels, one of the plants from each pot was dried in an incubator and ground in a Willey mill to create a fine powder. The powder was sent to the Fertilizer Laboratory (Laboratório de Fertilizantes_LAFER) at the Federal University of Uberlândia (Universidade Federal de Uberlândia-UFU) to measure the concentrations of silicon level.

The experiment used a completely randomized design including the following four treatments: T1) Susceptible cultivar (SP801842) without the application of silicon; T2) Susceptible cultivar (SP801842) with the application of silicon; T3) Moderate pest resistance cultivar (RB72454) without the application of silicon; T4) Moderate pest resistance cultivar (RB72454) with the application of silicon. Each treatment had ten replicates, except for the lignin and silicon contents, which had six replicates.

The data were subjected to an analysis of variance (ANOVA), and the averages were compared by the Tukey test $(p \leq 0.05)$ using a statistical program (SAEG) [8].

\section{Results and Discussion}

We found that the aerial fresh mass, was significantly higher in the sucesptible cultivar (SP801842) treated with silicon than in those of any other treatment. The same cultivar showed lowest fresh mass without silicon application and was found to be statistically equal to those of moderate resistance cultivar (RB72454) with and without silicon application (Table 1).

The dry mass of the aerial portions of both cultivars increased after silicon application, and the highest value (45.9 g) was found in susceptible cultivar (SP801842) (Table 1). Cultivars without silicon treatment recorded low dry mass and were not significantly different from each other. Dry mass values of $18.2 \mathrm{~g}$ and $15.4 \mathrm{~g}$ were recorded for the moderately resistant and susceptible cultivars, respectively.

The fresh mass of the root of both cultivars was significantly higher without the silicon application. Similar result was observed for the dry masses of the roots; plants without silicon had higher masses than those that underwent silicon treatment (Table 1).

Previous studies have suggested that silicon may increase the leaf dry mass and both the dry and fresh masses of the roots [9]-[12]. Reports have also indicated that silicon accumulates in the support and sustenance tissues of the stems, strengthening the plant structure [13]. The results obtained here only partially agree with those of these researchers, as we found that the root mass of sugarcane was reduced after silicon application.

The susceptible cultivar responded positively to silicon application, resulting in increased fresh and dry masses of the aerial portions of the plant, while only the dry mass of the moderately resistant cultivar benefited. These results are consistent with those of [14], who found that the application of calcium silicate in increasing

Table 1. The fresh and dry masses (g) of the aerial portions and roots of plants from two cultivars of sugarcane, one moderately resistant (MR) and another susceptible (S), with and without silicon (Si) application. The data shown are the average \pm standard error.

\begin{tabular}{|c|c|c|c|c|}
\hline \multirow{2}{*}{ Treatment } & \multicolumn{2}{|c|}{ Aerial portions } & \multicolumn{2}{|c|}{ Roots } \\
\hline & Fresh mass (g) & Dry mass (g) & Fresh mass (g) & Dry mass (g) \\
\hline RB72454 (MR) & $83.1 \pm 3.5 b$ & $18.2 \pm 0.8 c$ & $319.5 \pm 19.1 \mathrm{a}$ & $84.9 \pm 10.4 a$ \\
\hline RB72454 (MR) + Si & $85.7 \pm 5.7 b$ & $37.9 \pm 2.1 b$ & $196.5 \pm 15.6 b$ & $37.4 \pm 5.7 b$ \\
\hline SP801842 (S) & $66.1 \pm 5.7 b$ & $15.4 \pm 1.3 c$ & $345.5 \pm 35.3 a$ & $72.4 \pm 13.1 \mathrm{a}$ \\
\hline SP801842 (S) + Si & $126.4 \pm 9.3 a$ & $45.9 \pm 2.8 a$ & $158.5 \pm 4.5 b$ & $28.8 \pm 1.9 b$ \\
\hline CV (\%) & 22.48 & 20.35 & 27.37 & 49.11 \\
\hline
\end{tabular}

Averages in a column that are followed by the same letter were not found to be significantly different by the Tukey test ( $p \leq 0.05)$. 
amounts during planting increased the dry mass of the aerial portions of Brachiaria brizantha accordingly. Similar results were found by [15] for elephant grass.

However, the fresh and dry masses of the roots were lower in the silicon treatments of both cultivars, a result similar to that found by [16] in coffee trees, where silicate fertilization decreased root dry mass accumulation.

In rice, doses above $0.38 \mathrm{~g} \cdot \mathrm{dm}^{-3}$ silicon were found to decrease the size of the root system, possibly due to phytotoxicity [17], which is also a potential explanation for the results of the present study. In other studies on rice, however, the application of silicon did not alter the dry mass production in the roots [18] [19]. Thus, it is difficult to determine whether silicon affects root development and what could cause the observed dry mass reduction.

The chlorophyll levels were also different between the treatments and were significantly higher in the plants of both cultivars that were treated with silicon (Table 2). Silicon may stimulate the plants to concentrate chlorophyll in the leaves. This result has also been observed in tomato vines [20] and rice plants [18], possibly validating the results of the present study. This chlorophyll concentration occurs because silicon is linked to the maintenance of photosynthesis as well as to chlorophyll distribution preservation and protection from the structural and functional breakdown of the cell membranes [21].

However, only the silicon levels of the aerial portions of the susceptible cultivar, SP801842, were increased by silicon application, with results $40 \%$ higher than in the untreated plants (Table 2). The silicon levels in the treated susceptible cultivar were statistically equal to the levels found in the moderately resistant cultivar, suggesting that an accumulation of this element is one of the components involved in this cultivar's resistance to $D$. saccharalis. In rice plants that were treated with silicon, there was a linear increase in the plant's accumulation of the element as the applied dose increased [17] [22], confirming the results of the study.

The incidence of $D$. saccharalis in all of the treatments was very low (Table 3), despite the artificial infestation that was performed on the plants. This may be due to the difficulties the caterpillars had in adapting to sugarcane leaves after they were initially raised on an artificial diet. In the moderately resistant cultivar, RB72454, none of the plants had dead heart symptoms, and caterpillars and pupae were completely absent. In the susceptible cultivar, SP801842, symptoms of $D$. saccharalis infestation were limited to a few cases; therefore, the results are not consistent enough to conclude whether silicon would benefit sugarcane by impeding infestations by this pest.

However, field studies conducted in South Africa demonstrated that silicon application promoted Eldana saccharina Walker (Lepidoptera: Pyralidae) resistance in sugarcane [23]-[26]. As these are related pests, one would expect similar results, but further field studies are needed to validate this technique's effectiveness.

Table 2. The chlorophyll and silicon levels in the aerial portions of plants from two cultivars of sugarcane, one moderately resistant (MR) and another susceptible (S), with and without silicon (Si) application. The data shown are the average \pm standard error.

\begin{tabular}{ccc}
\hline Treatment & Chlorophyll level (SPAD) & Silicon level (\%) \\
\hline RB72454 (MR) & $34.9 \pm 0.75 \mathrm{~b}$ & $0.66 \pm 0.04 \mathrm{a}$ \\
RB72454 (MR) + Si & $45.5 \pm 1.05 \mathrm{a}$ & $0.64 \pm 0.05 \mathrm{ab}$ \\
SP801842 (S) & $36.1 \pm 0.62 \mathrm{~b}$ & $0.48 \pm 0.01 \mathrm{~b}$ \\
SP801842 (S) + Si & $43.7 \pm 0.68 \mathrm{a}$ & $0.68 \pm 0.05 \mathrm{a}$ \\
CV (\%) & 6.29 & 16.59 \\
\hline
\end{tabular}

Averages in a column that are followed by the same letter were not found to be significantly different by the Tukey test $(p \leq 0.05)$.

Table 3. The number of plants with $D$. saccharalis caterpillars and pupae and symptoms of "dead heart" in two cultivars of sugarcane, one moderately resistant (MR) and another susceptible (S), with and without silicon (Si) application.

\begin{tabular}{cccc}
\hline Treatment & Dead heart $^{*}$ & Caterpillars $^{*}$ & Number $^{*}$ \\
\cline { 3 - 4 } & & 0 & 0 \\
RB72454 (MR) & 0 & 0 & 0 \\
RB72454 (MR) + Si & 0 & 1 & 3 \\
SP801842 (S) & 2 & 1 & 2 \\
SP801842 (S) + Si & 1 & 1 & Pupae \\
\hline
\end{tabular}

\footnotetext{
*Statistical analysis was not performed due to the low number of observed data points.
} 
Overall, silicon was beneficial for the growth of the aerial portion of sugarcane plants, particularly by significantly increasing their chlorophyll levels. Sugarcane also reacted positively to silicon application by accumulating the compound in its stems and leaves, using it to form one of the components of its barriers against caterpillar penetration into the stalk.

\section{Conclusions}

Silicon application is beneficial for the growth of the aerial portions of sugarcane, particularly susceptible cultivar and significantly increases — chlorophyll levels of resistant as well as sucepticle cultivar.

Though the number of plant showing dead rot and number of pupae decreased in silicon treated susceptible cultivar, further investigation on role of silicon on imparting resistance to $D$. saccharalis is required as a low infestation rate of insect pest observed in present experiment.

\section{Acknowledgements}

The authors thank the National Council for Scientific and Technological Development (Conselho Nacional de Desenvolvimento Científico e Tecnológico-CNPq) for providing a fellowship and other financial support as well as the Minas Gerais Research Foundation (Fundação de Pesquisa de Minas Gerais-FAPEMIG) for their financial support.

\section{References}

[1] Agrianual (2013) Anuário da agricultura brasileira. Informa Economics FNP, São Paulo, 480 p.

[2] Companhia Nacional de Abastecimento. Acompanhamento da safra brasileira de 2008 de cana-de-açúcar. http://www.conab.gov.br/OlalaCMS/uploads/arquivos/12 $090509 \quad 1159$ boletim cana portugues - agosto 2012 2o lev.pdf

[3] Almeida, L.C. and Stingel, E. (2005) Curso de monitoramento e controle de pragas da cana-de-açúcar. Centro de Tecnologia Canavieira, Piracicaba, 32 p.

[4] Anderson, D.L. (1991) Soil and Leaf Nutrient Interaction Following Application of Calcium Silicate Slag to Sugarcane. Fertilizer Research, 30, 9-18.

[5] Raid, R.N., Anderson, D.L. and Ulloa, M.F. (1992) Influence of Cultivar and Amendment of Soil with Calcium Silicate Slag on Foliar Disease Development and Yield of Sugarcane. Crop Protection, 11, 84-88.

[6] de Filho, O.F., de Lima, M.T.G. and Tsai, S.M. (1999) O silício na agricultura. Encarte técnico Informações agronômicas, 87, 1-12.

[7] King, E.G. and Hartley, G.G. (1985) Diatraea saccharalis. In: Singh, P. and Moore, R.F., Eds., Handbook of Insect Rearing, Elsevier, New York, 265-270.

[8] Ribeiro Jr., J.I. (2001) Análises estatísticas no SAEG. UFV, Viçosa, 301 p.

[9] Barbosa Filho, M.P., Snyder, G.H., Prabhu, A.S., Datnoff, L.E. and Korndorfer, G.H. (2000) Importância do silício para a cultura do arroz: uma revisão de literatura. Informações Agronômicas, 89, 1-8. http://ainfo.cnptia.embrapa.br/digital/bitstream/item/79663/1/Barbosa-Filho.pdf

[10] Korndörfer, G.H., Pereira, H.S. and Camargo, M.S. (2002) Papel do silício na produção de cana-de-açúcar. Revista da Sociedade dos Técnicos Açucareiros e Alcooleiros do Brasil, 21, 34-37. http://www.malavolta.com.br/pdf/1072.pdf

[11] Korndörfer, G.H., Pereira, H.S. and Camargo, M.S. (2004) Silicatos de cálcio e magnésio na agricultura. 3rd Edition, UFU/ICIAG, Uberlândia.

[12] Carvalho Filho, A., Pereira, L.J., Cortez, J.W., Carvalho, L.C.C. and Drumond, L.C.D. (2007) Agressividade da adubação com silicato sobre germinação do milho. Scientia Agraria, 8, 199-203.

[13] Plucknett, D.L. (1971) The Use Soluble Silicates in Hawaii Agriculture. Journal of the University of Queensland, 1, 203-223.

[14] Souza, E.A., Moraes, J.C., Amaral, J.L., Liberato, R.D., Bonelli, E.A. and Lima, L.R. (2009) Efeito da aplicação de silicato de cálcio em Brachiaria brizantha cv. Marandu sobre a população de ninfas do percevejo castanho das raízes Staptocoris carvalhoi Becker, 1967, características químicas do solo, planta e produção de matéria seca. Ciência e Agrotecnologia, 33, 1518-1526.

[15] Vilela, H., Andrade, R.A. and Vilela, D. (2007) Efeito de níveis de silicato sobre a correção do solo, produção e valor nutritivo do capim elefante paraíso (Pennisetum hybridum). In: Simpósio brasileiro sobre silício na agricultura, Vol. 4, 
FEALQ, Piracicaba, 9-13.

[16] Ribeiro, R.V., Silva, L., Ramos, R.A., Andrade, C.A., Zambrosi, F.C.B. and Pereira, S.P. (2011) O alto teor de silício no solo inibe o crescimento radicular de cafeeiros sem afetar as trocas gasosas foliares. Revista Brasileira de Ciências do Solo, 35, 939-948.

[17] Faria Jr., L.A., Carvalho, J.G., Pinho, P.J., Bastos, A.R.R. and Ferreira, E.V.O. (2009) Produção de matéria seca, teor e acúmulo de silício em cultivares de arroz sob doses de silício. Ciência e Agrotecnologia, 33, 1034-1040. http://www.scielo.br/pdf/cagro/v33n4/a13v33n4.pdf

[18] Ávila, F.W., Baliza, D.P., Faquin, V., Araújo, J.L. and Ramos, S.J. (2010) Interação entre silício e nitrogênio em arroz cultivado sob solução nutritiva. Revista Ciência Agronômica, 41, 184-190.

http://www.ccarevista.ufc.br/seer/index.php/ccarevista/article/view/470/444

[19] Gomes, C.F., Marchetti, M.E., Novelino, J.O., Mauad, M. and Alovisi, A.M.T. (2011) Disponibilidade de silício para a cultura do arroz, em função de fontes, tempo de incubação e classes de solo. Pesquisa Agropecuária Tropical, 41, 531538. http://www.revistas.ufg.br/index.php/pat/article/view/10906

[20] Emrich, E.B., Souza, R.J., Lima, A.A., Figueiredo, F.C. and Silva, D.R.G. (2011) Cultivo do tomateiro em substratos orgânicos sob aplicação foliar de silicato de potássio em ambiente protegido. Ciência e Agrotecnologia, 35, 56-61. http://www.scielo.br/pdf/cagro/v35n1/a06v35n1.pdf

[21] Agarie, S., Agata, W. and Kaufman, P.B. (1998) Involvement of Silicon in the Senescence of Rice Leaves. Plant Production Science, 1, 104-105. https://www.jstage.jst.go.jp/article/pps1998/1/2/1_2_104/_pdf

[22] Ramos, L.A., Korndorfer, G.H. and Queiroz, A.A. (2009) Avaliação de fontes de silício em plantas de arroz do ecossistema de várzea. Bioscience Journal, 25, 10-16.

[23] Keeping, M.G. and Meyer, J.H. (2002) Calcium Silicate Enhances Resistance of Sugarcane to the African Stalk Eldana saccharina Walker (Lepidoptera: Pyralidae). Agricultural and Forest Entomology, 4, 265-274. http://onlinelibrary.wiley.com/doi/10.1046/j.1461-9563.2002.00150.x/abstract

[24] Keeping, M.G. and Meyer, J.H. (2006) Silicon-Mediated Resistance of Sugarcane to Eldana saccharina Walker (Lepidoptera: Pyralidae): Effects of Silicon Source and Cultivar. Journal of Applied Entomology, 130, 410-420. http://onlinelibrary.wiley.com/doi/10.1111/j.1439-0418.2006.01081.x/abstract

[25] Kvedaras, O.L., Keeping, M.G., Geobel, R. and Byrne, M. (2005) Effects of Silicon on the African Stalk Borer, Eldana saccharina (Lepidoptera: Pyralidae) in Sugarcane. Proceedings of the 79th Annual Congress of the South African Sugar Technologists' Association, South African Sugar Technologists Association, Durban, 359-362.

[26] Kvedaras, O.L. and Keeping, M.G. (2007) Silicon Impedes Stalk Penetration by the Borer Eldana saccharina in Sugarcane. Entomologia Experimentalis et Applicata, 125, 103-110. http://onlinelibrary.wiley.com/doi/10.1111/j.1570-7458.2007.00604.x/pdf 
Scientific Research Publishing (SCIRP) is one of the largest Open Access journal publishers. It is currently publishing more than 200 open access, online, peer-reviewed journals covering a wide range of academic disciplines. SCIRP serves the worldwide academic communities and contributes to the progress and application of science with its publication.

Other selected journals from SCIRP are listed as below. Submit your manuscript to us via either submit@scirp.org or Online Submission Portal.
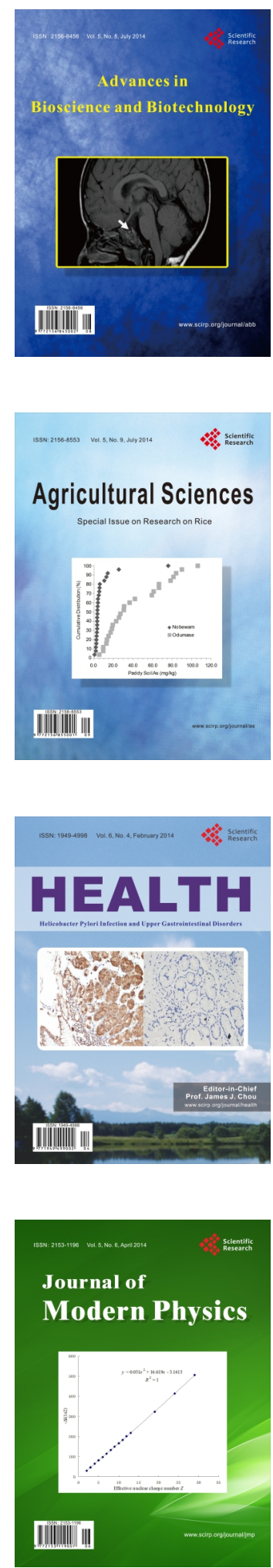
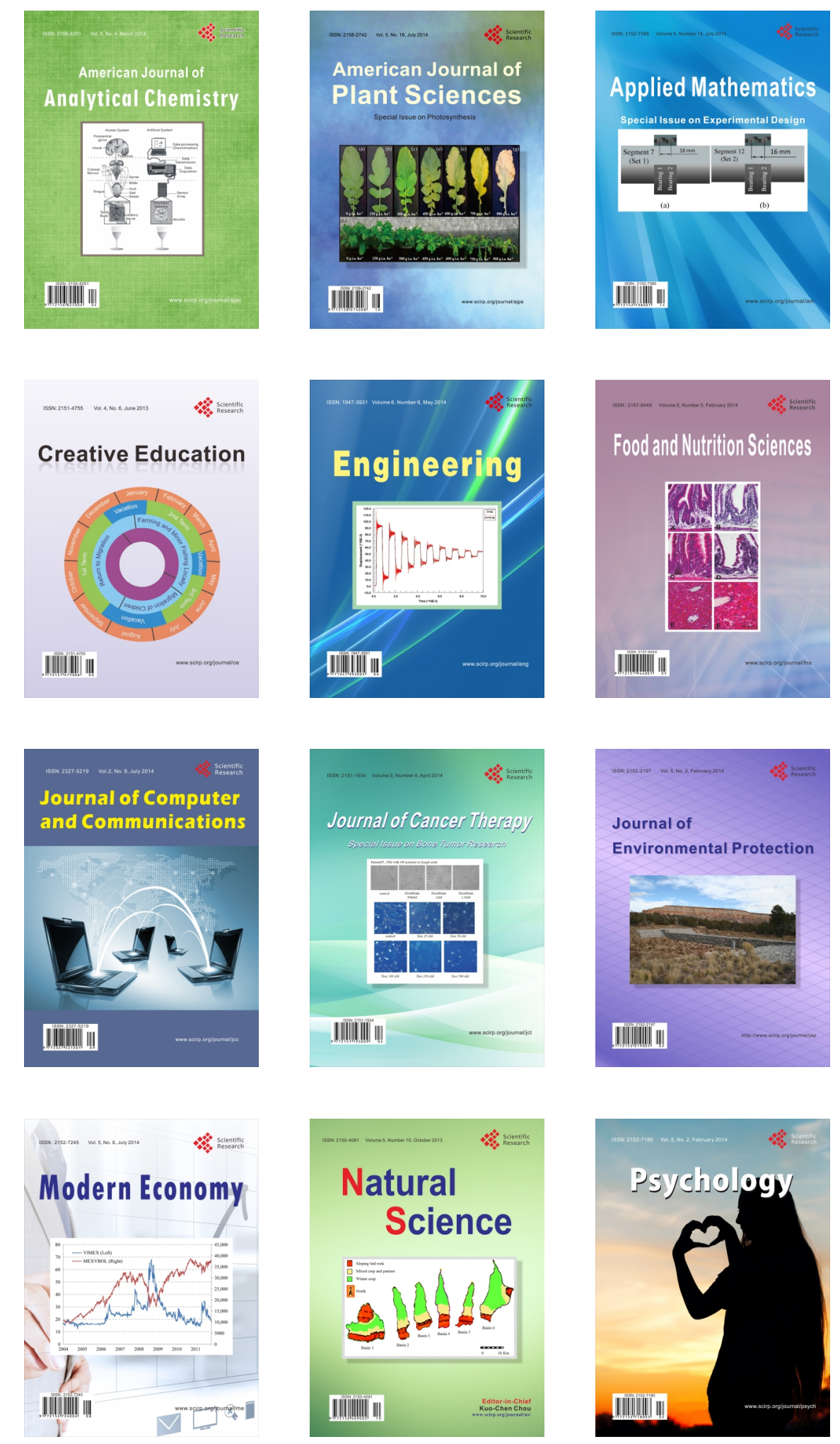